Fundamentals of Physics 
THE OPEN YALE COURSES SERIES is designed to bring the depth and breadth of a Yale education to a wide variety of readers. Based on Yale's Open Yale Courses program (http://oyc.yale.edu), these books bring outstanding lectures by Yale faculty to the curious reader, whether student or adult. Covering a wide variety of topics across disciplines in the social sciences, physical sciences, and humanities, Open Yale Courses books offer accessible introductions at affordable prices.

The production of Open Yale Courses for the Internet was made possible by a grant from the William and Flora Hewlett Foundation.

\section{RECENT T I T L ES}

Paul H. Fry, Theory of Literature

Christine Hayes, Introduction to the Bible

Shelly Kagan, Death

Dale B. Martin, New Testament History and Literature

Giuseppe Mazzotta, Reading Dante

R. Shankar, Fundamentals of Physics

Ian Shapiro, The Moral Foundations of Politics

Steven B. Smith, Political Philosophy 


\title{
Fundamentals of Physics
}

Mechanics, Relativity, and Thermodynamics

R. S H A N K A R

\author{
Yale \\ UNIVERSITY PRESS
}

New Haven and London 
Published with assistance from the foundation established in memory of Amasa Stone Mather of the Class of 1907, Yale College.

\section{Copyright (C) 2014 by Yale University.}

All rights reserved.

This book may not be reproduced, in whole or in part, including illustrations, in any form (beyond that copying permitted by Sections 107 and 108 of the U.S. Copyright Law and except by reviewers for the public press), without written permission from the publishers.

Yale University Press books may be purchased in quantity for educational, business, or promotional use. For information, please e-mail sales.press@ yale.edu (U.S. office) or sales@yaleup.co.uk (U.K. office).

Set in Minion type by Newgen North America.

Printed in the United States of America.

ISBN: 978-0-300-19220-9

Library of Congress Control Number: 2013947491

A catalogue record for this book is available from the British Library.

This paper meets the requirements of ANSI/NISO Z39.48-1992 (Permanence of Paper).

10987654321 
To my students

for their friendship and inspiration 


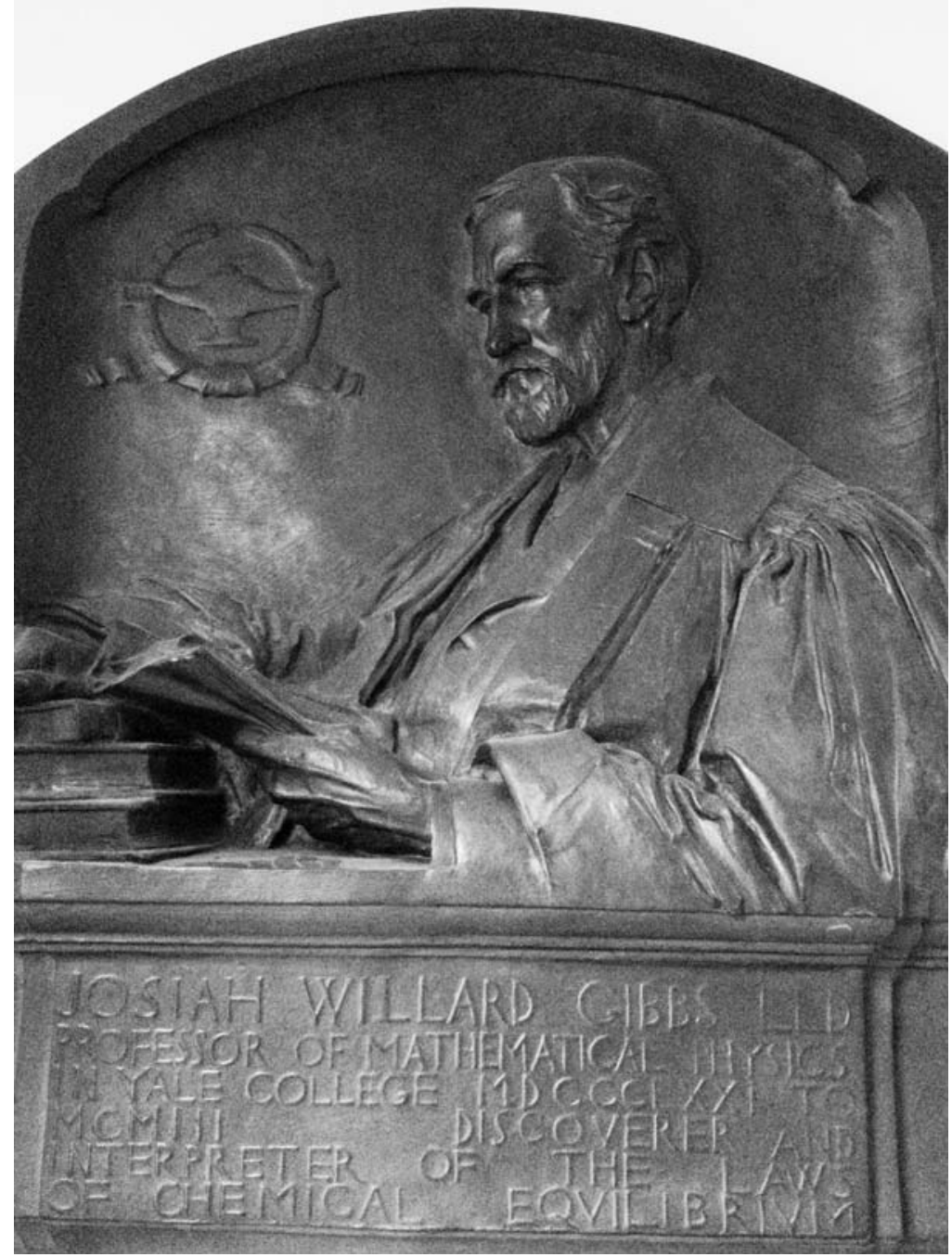

Deep and original, but also humble and generous, the physicist Josiah Willard Gibbs spent much of his life at Yale University. His father was a professor of sacred languages at Yale, and Gibbs received his bachelor's and doctorate degrees from the university before teaching there until his death in 1903. The sculptor Lee Lawrie created the memorial bronze tablet pictured above, which was installed in Yale's Sloane Physics Laboratory in 1912. It now resides in the entrance to the J. W. Gibbs Laboratories, Yale University. 